\title{
Putting a Price Tag on Human Rights. An Anthropological Perspective on Nestle's Drinking Water Privatisation in Pakistan
}

\begin{abstract}
In the $21^{\text {st }}$ century, the time of globalisation, capitalism and rising populations, resources are running low and for many rural communities, natural resource exploitations and therefore insecurities become a real danger. Due to the groundwater exploitation in Pakistan, dwells in small villages dry out or become inaccessible to the local inhabitants, which forces them to drink polluted surface water in order to survive. Having to drink polluted surface water results in rising number of diseases in these areas. With the help of Critical Discourse Analysis, this essay aims to analyse the power relations and interconnectedness of the different discourse partakers' lines of argumentations on the privatisation of natural resources by applying Foucauldian Perspective to the given context. The lines of argumentation will be explored on behalf of the example of Nestle's drinking water privatisation practices in Pakistan. Firstly, it will provide a short introduction of the anthropological perspective on resource insecurities. To adequately analyse the discourse, following questions will be taken into consideration: Can water be considered as a human right? What is an anthropological perspective on resource insecurities? How is the current drinking water situation in Pakistan? How is Nestle privatising ground water in Pakistan and what are the consequences for the native inhabitants? How are CEO's, NGO's, activists, locals and governments reacting to this situation? How can power relations between these actors be uncovered and how do different partakers position themselves in a social context? Conclusively, this essay will take an outlook on possible solutions that are being proposed by different respective actors, such as environmental activists, governments and corporations. It is hoped that this essay will give readers a general overview on the current situation and practices of resource privatisation seen from both an anthropological and an analytical perspective.
\end{abstract}

Keywords: Nestle, Pakistan, drinking water, privatisation of natural resources, pure life, human rights. 
The processes of resource extraction generate a constant reworking of the boundaries between nature and culture, between

"things, that already are" within different cosmologies and the human or socially produced (cf. Ferry \& Limbert 2008: 6).

\section{Introduction: water as human rights}

Since the start/beginning of the $21^{\text {st }}$ century natural resources such as water, oil and land are more in demand than ever. But over time, our resources have started to diminish.

Access to improved drinking water is not just a necessity for human survival and development, but also a basic human right (Universal Declaration of Human Rights 1948: 71). The Food and Agriculture Organisation of the United Nation (FAO) defines food security as "a situation that exists when all people, at all times, have physical, social, and economic access to sufficient, safe, and nutritious food that meets their dietary needs and food preferences for an active and healthy life (FAO 2002)" (see Wutich \& Brewis 2014: 444-468). The normative demand for the Human Right to Water is derived from the Universal Declaration of Human Rights (Universal Declaration of Human Rights 1948: 71). It implicitly recognised the right to drinking water and sanitation in article 25 (1), which states that "everyone has the right to a standard of living adequate for the health and well-being of himself and of his family, including food, clothing, housing and medical care..." It is repeated in Article 11 of the International Covenant on Economic, Social and Cultural Rights, as part of the right of everyone to an adequate standard of living for himself and his family. ${ }^{1}$ In previous comments by the UN Committee on Economic, Social and Cultural Rights, ${ }^{2}$ in addition to various human rights protection mechanisms, the human right to water is treated as a precondition for other human rights - such as the human right to live, to appropriate nutrition and sufficient medical care. In 1994, after mining companies polluted local drinking water in Pakistan, the Supreme Court of Pakistan expanded Art. 9 of the right to life and said: "the right to have unpolluted water is a right of every person, wherever he lives." When acting independently due to market positions and economic power, Transnational Corporations are obligated to ensure respect to human rights recognised in international and national human rights, ${ }^{3}$ as well as in accordance with

${ }^{1}$ Adopted by General Assembly Resolution 2200 A (XXI) of December 16, 1966; ICescR entered into force on January 03, 1976; U.N. Doc. A/RES/2200 A (XXI).

2 See among other the General Comment No. 12 (1999) with regard to the right to food and No. 15 (2000) with regard to the right to health; U.N. Doc. HRI/GEN/1/Rev.5.

${ }^{3}$ United Nations Sub-Commission on the Promotion and Protection of Human Rights: Norms of the responsibility of transnational corporations and other business enterprises with regard to human rights, U.N. Doc. E/CN.4/Sub.2/2003/12/Rev.2, Article 1; adopted with Commentary, U.N. 
fair business, marketing, advertising and distribution practices that shall not put consumers in any danger. ${ }^{4}$

So how can a basic human right be privately owned by globalised, capitalistic, profit-oriented corporations? As Indian author Vandana Shiva states in her book called Water Wars: "When private companies make large profits through high water prices, it denies the poor the inalienable right to the most necessary substance for life." When private corporations buy, or distribute public water resources, it is often proposed to be a solution to budget problems and insufficient water systems. Worldwide private ownership of water utilities has been growing for a number of years. According to a 2004 editorial by Gary H. Wolff in the "Journal of Water Resources Planning and Management" the number of people served by private water companies worldwide grew from 51 million in 1990 to nearly 300 million in 2002. ${ }^{6}$ The World Bank and International Monetary Fund (IMF) are pushing for the privatization of water services by European and U.S.-based companies by stipulations on trade agreements and improved loan conditions to developing countries. This tends to impose loan conditions to guarantee international corporations certain profit margins on the business with water. ${ }^{7}$

This essay aims to examine the media discourse of human rights and the privatisation of natural resources exemplified by the privatisation of fresh water in Pakistan by the global concern "Nestle Waters". Additionally, it will attempt to show how discourse is created and constructed by the different partaking actors and the power relations that are to be uncovered within these argumentations. The theoretical aims are aforementioned, there will also be an emphasis put on the impacts these privatisation procedures have on the affected indigenous, rural communities of the small village Bhati Dilwan, Pakistan. In regards to the methodology of this paper, the method of critical discourse analysis (CDA) will be used. The analysis of the discursive topic of privatisation of natural resources will follow the comparison and contextualisation of the different actors' chains of reasoning. This should give the reader an insight on how this topic is perceived and handled by different discourse partakers in a multimedia environment.

Doc. E/CN.4/Sub.2/2003/38/Rev.2, by Resolution 2003/16 on August 13, 2003, U.N. Doc. E/CN.4/ Sub.2/RES/2003/16.

${ }^{4}$ Ibid., Article 13.

${ }^{5} \mathrm{http}: / /$ academic.evergreen.edu/g/grossmaz/VANOVEDR/ (access: 16.03.2017).

${ }^{6} \mathrm{http}: / /$ blogs.ei.columbia.edu/2010/09/02/what-is-the-benefit-of-privatizing-water/ (access: 16. 03. 2017).

${ }^{7}$ http://america.aljazeera.com/opinions/2014/4/water-managementprivatizationworldbankgroupifc.html (access: 15.03.2017). 


\section{Critical discourse analysis and methodology}

Discourses and its interlocking systems of knowledge, truth and power are defined as the result and base of human action in a socio-historical process and must be deconstructed by analysing the social interactions and discovering the inherent exclusions and restrictions given (Bartel, Ulrich \& Ehrlich 2008 54). Hereby, it is important to take the internal relationships of these positions into account, as well as to put them into a social context, to be able to explain their power relations. Often, the purpose of critique is to reveal the structures of power and unmasking ideologies. CDA therefore is interested in the way that discourse (re) produces social dominations, that is, "the power abuse of one group over others, and how dominated groups may discursively resist such abuse" (Wodak 2009, 8). This paper will use the word "power" in relation to the Foucauldian interpretation of power, namely power "as a result from discursive structures, (scientific) knowledge and practices that accompany them which create a set of rules and standards, with reference to agents may exercise power over other agents, as well as over themselves" (Manokha 2009: 430). Any social discourse consists of different discourse levels (depending on focus: media, everyday culture, politics, medicine etc.). Each of these levels (re)produces discourses within its own rules and is respectively combined with the other levels (Bartel, Ulrich \& Ehrlich 2008: 57). In this paper, the focus will lie on the discourse of given topic practiced within the multimedia environment (media level). Discourse positions show the perspectives held by different actors, people or institutions contributing to and taking part in the respective discourse. The relationship between fresh water privatisation in Pakistan and the effect it has on the rural communities will be monitored by linking Nestles business procedures in Sheikhupura with simultaneous alterations in the rural peoples' landscape realities and therefore also the caused change in their access to clean drinking water. Additionally, this linkage will be sustained by anthropological contributions which previously elaborated on similar concerns. Sources chosen for my CDA will mostly consist of second hand online content (websites, blogs, multi-media content), reason being its accessibility for a large amount of the worlds' population and hence the potentiality of providing a diversity of chains of argumentations and perceptions. This paper especially focuses on sources published within the time period of 2012 until today, because the documentary movie Bottled Life by Urs Schnell, which will play a major role in the course of this essay, was released in 2012 and was followed by a wave of multimedia responses, online petitions and attention in online media and newspapers. Moreover, it is important to mention that CDA is considered a tool to show how specific actors construct an argument and what statements they try to establish as true, yet not to give an insight about how a whole society thinks and believes, as this would need standardisation processes and would end in a lack of profound grounds of scientific analysis. 
In this essay, firstly, it is necessary to mention some of the scientific and theoretical contributions on this paper's concern that were already established by Anthropologists. Secondly, it is important to get an insight into the general drinking water situation in Pakistan and explore the statistics, numbers and facts, additionally to a closer look on what privatisation of water means in particular for (a) Nestle and in this case (b) the rural population of Bhati Dilwan and how the different actors' argumentations are constructed. Thirdly, it will be the purpose to examine the power relations of the discourse partakers. Conclusively, this essay will try to take a deeper look on possible solutions and recommendations, which are presented by online communities, environmental activists or experts.

\section{Anthropological perspectives on resource insecurities}

To adequately examine the situation of drinking water privatisation in Pakistan, firstly it is necessary to refer back to existing anthropological research and perspectives on the topic of resource privatisation and resource insecurities in general. The revival of anthropological research on those natural resources rises from the dilemma between the states and international corporation's efforts to extract resources to ensure ongoing prosperity to their citizens and the contradictory violence of the state - sanctioned interventions on indigenous and rural lands. These interventions seem to have a growing impact on the people and places anthropologists study (Richardson, Weszkalnys 2014: 5). In the Introduction to the Article Resource Materialities Tanja Richardson proposes a theoretical framework that assumes that we are dealing with relational phenomena of what we call "Resource Materialities", which is meant to involve the "combined examination of the matters, knowledge, infrastructures, and experiences that come together in the appreciation, extraction, processing, and consumption of natural resources" (Richardson, Weszkalnys 2014: 8). Whereas theoretical concepts concerning people facing problems (i.e. hunger) are better developed (Hadley \& Crooks 2012: 72-94) the anthropological perspective on the lack of drinkable water is limited (Orlove \& Caton 2010: 401-415). In their article on Resource Insecurities, Amber Wutich and Alexandra Brewis compare and test preexisting theoretical frameworks regarding food against existing water related evidence. Furthermore, they draw attention to five key drivers, which are recognised to explain community-level differences in susceptibility to food insecurities. Following their argumentation, these are "(a) ecology, (b) population, (c) governance, (d) markets, and (e) entitlements (Butterley \& Sheperd 2010; Devereux 1993; Hadley \& Crooks 2012). Across these, institutions - that is, the rules and norms that govern resource ownership and distribution (Ostrom 1990) - are arguably the most influential" (Wutich \& Brewis 2014: 445). In the age of capitalism and neoliberalism the relevant key driver for my analysis will be the social and economic construct of the free mar- 
ket. Possibly because of the diversity of private sector roles in water distribution and management (and the lack of possibility to track unregulated markets), the vagaries of water markets are not as well studied yet. In many western countries, water markets are regulated and managed by the government, which is putting the cost of water within the reach of the poorest citizens (Rogers et al. 2002: 1-17). Unfortunately, when water costs are unreasonably subsidized, it reflects on the poor which must then bear the full costs of private water delivery. In this cases, poverty and water shortage are to be linked. As will be seen in the analysis of Nestle's water privatisation practices in Pakistan, from a Marxist perspective it is also necessary to take capitalism and neoliberalism into consideration to be key drivers of water insecurity among certain communities. But how can a capitalistic free market system have an influence on the discourse on human right to water? Firstly, we have to look at the relationship of economy and ecology, which was already looked into by several anthropologists, to afterwards understand the construction of the lines of argumentations of the involved actors in our case studies in Pakistan. Columbian-American Anthropologist Arturo Escobar describes the dispersions of power concerning the relationship between capitalist ideology and development following:

The discursive nature of capital is evident in various ways - for instance, in the resignification of nature as resources; in the construction of poverty as lack of development, of peasants as merely food producers. (...) The result is that, as they are being incorporated into the world capitalist economy, even the most remote communities in the Third World are torn apart from their local context and redefined as "resources" (Escobar 2012: 130, 194).

Escobar hereby critically analyses the reduction of nature, especially in the green/environmental movement, to "resources". He states that even the development apparatus therefore affirms and contributes to the spread of the dominant economic (capitalistic) worldview by focusing less on the negative consequences of economic growth on the environment than on the effects of environmental degradation on growth and potential for growth. Moreover, he uncovers the ecodevelopmentalistic worldview as an ideology putting focus on rather perpetuating capitalist market expansion, but the environment. The argument that growth is needed with the purpose of eliminating poverty, to in turn, protect the environment underlines the structural similarity of world perceptions and of both capitalistic and ecodevelopmentalistic views (Escobar 2012: 196-197). Similar analyses regarding economists can already be found in Wolfgang Sachs' contributions from 1988, where he describes economists as people who do more than simply proposing new strategies, as people that tell people how to see nature, society and their own actions. He characterises economists as people "who promote sustainability of nature and erode the sustainability of culture" (Sachs 1988: 39). Paul Farmer, Harvard Medical Anthropologist, also mentions doubts about the righteousness of handling resources as commodities. In one of his speeches to Harvard graduation classes, he insists that: 
we need to be aware that each of the terms and concepts and tools we've developed can be used to deny the destitute access to goods and services that should be rights, not commodities. They're not full participants in the magic market, after all. How many times have you heard that people will value something more if they have to pay for it? (Farmer \& Clinton 2013: 86)

So we established, that following the argumentation of the Anthropologists mentioned above, there must be an interconnection between the ideology of capitalism and free markets and the usage of this ideological construct to legitimise the privatisation of resources. Resources are therefore free to be traded as commodities. To understand this finding is necessary for later interpretation of different power relations within the given example.

Additionally, an anthropological perspective on resource insecurities should always highlight cultural and lifestyle-dimensions, as well as the adequacy of these insecurities:

Historical and ethnographic accounts demonstrate diversity in water regulation and use across cultures (e.g. Lansing et al., 1993; Little \& Leslie 1999), implying different expectations and requirements for water. Ethnographic work also points to culturally specific understandings of water insecurity. Rather than relying exclusively on proxy measures such as health indicators (Hasan et al. 1989; Checkley et al. 2004) or measures of physical access to water (e.g. time to source, quality of source, or quantity consumed [Whittington et al. 1990]), locally grounded research can generate experience-based measures of water insecurity, reflecting local idioms of stress and suffering. The advantages of this approach are that it measures the experience of water insecurity relatively directly, and it takes account of the social context of water use (Stevenson et al. 2012: 392-400).

As for example Wutich showed in a series of studies in Bolivia, women, who bore the majority of the burden of collecting water, reported greater water insecurity than men. Additionally, water insecurity, but not per capita water use as recorded in diaries, was found to be associated with emotional distress that included symptoms of anger, bother, fear, and worry (Wutich \& Ragsdale 2008: 2116-2125; Hadley \& Wutich 2009: 451-460). As can be seen, resource insecurities consist of a complex grid of reasons and consequences with a big variety of research fields, where suitable analysis and complete theoretical frameworks are yet to be better discovered.

\section{Local access to clean drinking water in Pakistan and the issues of its privatisation}

Access to improved drinking water supply is as much a necessity as it is considered a basic human right (Universal Declaration of Human Rights 1948: 71). "Improved" water supply technologies include: household connection, public standpipe, borehole, protected dug well, protected spring, and rainwater collection. "Not improved" include: unprotected well, unprotected spring, vendor-provided 
water, bottled water, and tanker truck-provided water. Access to an "improved source" also entails that the source is able to provide at least 20 liters per capita per day at a distance no more than 1000 meters from the user's residence (World Health Organisation... 2000: 77f.).

Unfortunately, in Pakistan an estimation of 44 percent of the population suffers from a lack of access to improved water supplies and clean drinking water. In rural areas, this number may even increase to a total of 90 percent of the population that has no such access (The United Nations System in Pakistan 2003: 63). This situation results in many health problems, which are caused by contaminated drinking water, such as diarrheal diseases, which again as a result lead to around 40 percent deaths within the country (Pakistan's water quality ranks as $80^{\text {th }}$ out of 122 nations $\left.^{8}\right) .{ }^{9}$ Due to these problems many consumers in Pakistan are forced to buy bottled drinking water, as it seems to be the only option for safe water consumption in the less-privileged, southern areas of Pakistan (Government of Pakistan 2003). However, bottled water is a very expensive substitute compared to an adequate service of drinkable tap water. But due to the lack of a proper water infrastructure and not enough available resources it is the only option people in Pakistan are left with. ${ }^{10}$ Another problem with Pakistan's water distribution is that only three percent of its sweet water resources are used for household purposes and drinking (Government of Pakistan 2002: 111). So, the countries' water organisation focuses on agriculture, rather than on people.

When private Corporations buy, or distribute public water resources, it is often proposed to be a solution to budget problems and insufficient water systems. Worldwide private ownership of water utilities has been growing for a number of years. According to a 2004 editorial by Gary H. Wolff in the "Journal of Water Resources Planning and Management" the number of people served by private water companies worldwide grew from 51 million in 1990 to nearly 300 million in 2002. ${ }^{11}$ The World Bank and International Monetary Fund (IMF) are pushing for the privatization of water services by European and U.S.-based companies by stipulations on trade agreements and improved loan conditions to developing countries. This tends to imposing loan conditions to guarantee international corporations certain profit margins on the business with water. ${ }^{12}$

${ }^{8}$ UNESCO: Water quality indicator values in selected countries, at: http://www.unesco.org/bpi/ wwdr/WWDR_chart2_eng.pdf (access: 13.03.2017).

${ }_{9}$ http://aaj.tv/2012/04/contaminated-water-contributes-to-40-death-in-pakistan-un/ (access: 16. 03.2017).

${ }^{10}$ World Health Organization (WHO): Bottled Drinking Water (Fact Sheet No. 256), Geneva 2000, available at: http://www.who.int/.

${ }^{11} \mathrm{http} / / /$ blogs.ei.columbia.edu/2010/09/02/what-is-the-benefit-of-privatizing-water/ (access: 16. 03.2017).

${ }^{12} \mathrm{http} / / /$ america.aljazeera.com/opinions/2014/4/water-managementprivatizationworldbankgroupifc.html (access: 15.03.2017). 
Privatisation of a natural resource as water includes consequences for the local public. The commercialisation and privatisation of water resources is controversially discussed. On the one hand, there is a strong opposition of people that question the handling of water purely as a commodity, rather than as a human right. On the other hand, water price increases as a result of reforms are unpopular and often combined with large consequences. Furthermore, increases in water fees tend to be regressive, influencing the poor more than richer segments of society. However, supporters of fresh water privatisation state that it has a good record of success improving the efficiency, quality and reliability of drinking water.

Privatisation of a natural resource (such as fresh water) means that the resource is taken out of the government's control and handed into the private sector of a company or corporation. This often results in a loss of transparency, a limitation of public accountability and increasing resource prices due to higher operating costs. ${ }^{13}$ Despite growing oppositions, in the new tendencies of globalisation and privatisation of natural recourses, there is an endeavor to replace collective ownership of natural water sources with corporate control.

\section{Nestle and the business of bottled water 'Pure Life' in Pakistan}

Nestle S.A. is a transnational corporation. It employs around 328,000 people in 418 factories in 86 countries, sells its products within 191 countries and operates in almost every country in the world with a total turnover of 83,5 billion euros in 2016. ${ }^{14}$ The corporation's water sector Nestle Waters, with a total of 51 different brands including Pure Life, San Pellegrino and Vittel, ${ }^{15}$ contributes 11,3 percent to the coalesced worldwide market share and is therefore world leader. ${ }^{16}$ Nestle Waters covers 93 production sites in 33 countries and employs a global workforce of 31,740 people. In 2008, Nestle Waters PURE LIFE bottled water has become the largest bottled water brand sold in the world. ${ }^{17}$ Nestle Waters records a total turnover of 7,141 million euros in 2015. ${ }^{18}$

As can be clearly seen in the statements above, currently Nestle Waters is one of the most important companies selling bottled water when it comes to economic power, numbers and profit in a capitalistic world. Nestle made great use of the idea using groundwater opposed to spring water, as spring water is highly regu-

${ }^{13}$ Readmore:http://www.foodandwaterwatch.org/insight/water-privatization-facts-and-figures (access: 16.03.2017).

${ }^{14} \mathrm{http}: / /$ www.nestle.com/aboutus/overview (access: 16.03.2017).

${ }^{15} \mathrm{http} / /$ www.nestle-waters.com/brands/all-brands/all-brands-list?char=B (access: 16.03.2017).

${ }^{16} \mathrm{http}: / /$ www.nestle-waters.com/bottled-water (access: 16.03.2017).

${ }_{17} \mathrm{http}: / /$ www.nestle-waters.com/aboutus (access: 16.03.2017).

${ }^{18} \mathrm{http} / / / \mathrm{www}$. nestle-waters.com/aboutus/key-figures (access: 16.03.2017). 
lated in Pakistan, whereas ground water shows a massive deficiency in regulation. As stated by writer Steven Meltzer on a website called urban times: "It represents today's neoliberalist and postcolonialist attitude of multinational giants who make profit by commodifying something that should not bear a price tag." ${ }^{19}$

Nevertheless, the Nestle Corporation declares direct commitments to human rights and stresses its responsibility as the world's leading food and beverage corporation, as well as the world leader in bottled waters, towards the sustainable use of fresh water resources. ${ }^{20}$ Besides the promise to respect human rights within its own sphere of operation, Nestlé links its bottled water policy with the MDG (Millennium Developmental Goals) to help decrease the number of people without access to safe drinking water or basic sanitation (Nestle 2003: 10).

But where does that bottled water come from? As safe, drinkable tap water is virtually not available in developing countries, they seem to qualify as a profitable market for bottled drinking water. That's why Nestle Waters found itself a niche in countries such as Ethiopia, Nigeria and Pakistan. Last mentioned is one of the main countries Nestle Waters is extracting drinking water from and selling it within. For example, in Lahore, Pakistan Nestle sells its Pure Life water to upper class citizens. Through several marketing campaigns Nestle succeeded in advancing Pure Life bottled water to a status symbol and a demonstration of purported health consciousness within the upper-class community in Lahore. ${ }^{21}$ This can be especially seen by a statement taken from the documentary movie Bottled Life (2012) by director Urs Schnell, which was published in 2012. In this documentary, Ahmad Rafay Alam, who works as an advocate in the high court of Lahore, states:

What has happened in the last 15 years in my own consciousness is that I have seen and witnessed a replacement of drinking water, a commodification of drinking water. I would not say that it is Nestlé that has done it. It has been a confluence of factors. Nestle appeared on the scene, it started providing Pure Life drinking water. All of a sudden Coke shows up, Pepsi shows up, then a whole bunch of private local manufactured water shows up as well, all producing clean water, because of the terribly old and creaky system of the sanitation authority. And then, before you know it, everywhere you go and you ask for a glass of water, you have to pay 15 rupees for it. ${ }^{22}$

Unfortunately, a direct application of Nestles self-commitment to human rights to its bottled water policy can't be seen in Pakistan's southern areas, as can be shown on behalf of the case of the village Bhati Dilwan. The first Nestle-Factory in Pakistan can be found in Sheikhupura, which is just next to the small village Bhati Dilwan. Since the factory was built, the village suffers from a lack of clean drinking water. The extraction of water from two deep wells has caused springs in the area to dry up and the water level of the village's fountains sunk from 30 me-

${ }^{19} \mathrm{http} / /$ urbantimes.co/2013/06/nestle-the-global-search-for-liquid-gold/ (access: 16.03.2017).

${ }^{20}$ Nestlé: Our Responsibility / Water, available at: http://www.nestle.com (access: 16.03.2017).

${ }^{21} \mathrm{http} / /$ urbantimes.co/2013/06/nestle-the-global-search-for-liquid-gold/ (access: 16.03.2017).

${ }^{22} \mathrm{http}: / /$ bottledlifefilm.com/index.php/downloads-for-media.html (access: 26.05.2017), presskit, p. 8. 
ters to 90-120 meters below sea level. Citizens have been deprived of their own means of extracting water and rendered dependent on the expensive bottled Pure Life brand for clean water. ${ }^{23}$ A statement from Umar Hayat, a former selectman from Bhati Dilwan/Sheikhupura, represents the despairs and worries of the local community in a more detailed way:

In our opinion Nestlé has taken our water from us. Nestlé put its own tube well in the factory. Now the water has become very dirty. The water level used to be at 100 feet, now the level is down to 300 to 400 feet. We worry a lot (...) We've asked Nestlé for a tube well. At least they should provide us with a small pipe with an outlet of water through the wall. With such a solution, we, the locals from the village, could fetch the water this way with cans. They would show us a little gesture. ${ }^{24}$

Due to these discrepancies between Nestles self-commitment to human rights and its actual practices, many human rights organisations criticise its expanding role in influencing public policy through its engagement in multi-stakeholder bodies, as the 2030 Water Resource Group or the UN Global Compact. ${ }^{25}$ In 2000, at the World Water Forum in the Netherlands (held by mostly corporations), Nestlé and other corporations with a financial interest in distributing, extracting and controlling the world's drinking water accomplished having people's legitimate access to it officially downgraded from a "right" to a specified "need". ${ }^{26}$ The Nestlé chairman and former CEO Peter Brabeck-Letmathe stated that:

It's a question of whether we should privatise the normal water supply for the population. And there are two different opinions on the matter. The one opinion, which I think is extreme, is represented by the NGOs, who bang on about declaring water a public right. That means that as a human being you should have a right to water. And the other view says that water is a foodstuff like any other, and like any other foodstuff should have a market value. Personally, I believe it is better to give a foodstuff a value. ${ }^{27}$

From an anthropological perspective his position would be comparative to "the opinions that resources are far from naturally occurring, and their exploitation is key to their very existence. According to the OED, an integral part of what makes something a resource is its use for an end, particularly the creation of wealth" (Richardson \& Weszkalnys 2014: 12). Similarly, Ferry and Limbert define resources as "objects and substances produced from 'nature' for human enrichment and use" (Ferry \& Limbert 2008: 3).

${ }^{23} \mathrm{http} / /$ www.3sat.de/page/?source=/boerse/magazin/169630/index.html (access: 16.03.2017).

${ }^{24} \mathrm{http}: / /$ bottledlifefilm.com/index.php/downloads-for-media.html (access: 26.05.2017), presskit, p. 9.

${ }^{25} \mathrm{http}: / /$ www.world-psi.org/en/organisations-denounce-nestles-new-human-rights-impactassessment (access: 24.05.2017).

${ }^{26} \mathrm{http} / / /$ urbantimes.co/2013/06/nestle-the-global-search-for-liquid-gold/ (access: 16.03.2017).

$27 \mathrm{https}: / / \mathrm{www}$. youtube.com/watch?v=qyAzxmN2s0w (access: 16.03.2017). 
Nestle and other companies have since been taking control of geological formations containing groundwater that local communities count on for drinking water - and selling and bottling it for profit. Additionally, United Nations Educational, Scientific and Cultural Organization (UNESCO), based on research in the Province of Sindh, suggests that "groundwater extraction at the present rate obviously exceeds the renewable volume (...) in many exploitation areas and is not sustainable long term" (The United Nations System in Pakistan 2003: 58). As mentioned before, Pakistan does also not have a regulated water management policy and legislation, which could maybe limit groundwater exploitation. ${ }^{28} \mathrm{Ex}$ amples from Sindh are showing that Pakistan's available groundwater monitoring systems are insufficient for establishing reliable data (The United Nations System in Pakistan 2003: 58). In the documentary movie Bottled Life mentioned above, Maude Barlow, who is a former UN senior advisor on water, calls Nestle a "water hunter" and a "predator", a "corporation which is looking for the last pure water in the world", ${ }^{29}$, moreover, she states:

When a company like Nestlé comes along and says, Pure Life is the answer, we're selling you your own ground water while nothing comes out of your faucets anymore or if it does it's undrinkable - that's more than irresponsible, that's practically a criminal act. ${ }^{30}$

As presented above, the short-sighted perspective to water from the side of sustainable management ignores a human rights approach to water. Nestlés water policy ends with the statement: "Water is a top priority for Nestlé - and always will be" (Nestle 2003: 63). The question is what this means concerning the human rights of people affected by water extraction and the in-affordability of its bottled water for the poor. All these factors lead to the risk of people's human right of health. Diminishing water resources are one of the main causes of many diseases. If people lose access to affordable or natural resources of drinking water, and in addition can't afford the alternative of bottled water, they have no choice but to depend on unsafe surface water resources.

As a response to Nestle Waters water extraction and selling procedures, environmental activists tried to help the drinking water situation in Pakistan by

${ }^{28}$ For regulation of surface water in the Province of Punjab see: Amended by Punjab Amendment Act 1952, Extension Act 1964. West Pakistan Amendment 1965, 1968. Ordinance 1970, and Punjab Amendment Ordinance 1970, 1971 and 1975; The Punjab Soil Reclamation Act, 1952 was Amended by West Pakistan Amendment Ordinance 1964, by which the Soil Reclamation Board was substituted by Land and Water Development Board; For regulation of groundwater in Province of Punjab see: Water and Power Development Authority, Act 1958, Punjab Soil Reclamation Act. 1952 and Rules issued in 1965.

${ }^{29} \mathrm{http} / /$ /bottledlifefilm.com/index.php/downloads-for-media.html(access: 26.05.2017), presskit, p. 7.

${ }^{30}$ https://canadians.org/fr/node/8154 (access: 24.05.2017). 
promoting several petitions against the corporation. ${ }^{31}$ But to solve the water crisis the Government of Pakistan, international agencies and NGOs must start to act. The situation must be acknowledged by those institutions and sufficient data needs to be collected. Additionally, Pakistan would need a legislated regulation of groundwater resources, as well as efficient monitoring systems. Lastly, Nestlé should be held accountable for its commitments regarding human rights and sustainability. Any political deal due to Nestles leadership position will create a grey zone in the rule of law and lead to a lack of accountability. On the other hand, Peter Brabeck, points out a different point of view. In his response statement to the documentary film Bottled Life, he admits that "water required for drinking and basic hygiene is without a question a human right; i.e., a minimum of $25 \mathrm{~L}$ per day per person, or $1.5 \%$ of global water withdrawal." In his opinion, this supply lies within the responsibility of governments. Yet, he states that he is not of the opinion that the rest of the 98.5 percent of water usage, including luxurious and unnecessary actions for human survival (such as watering of golf courses for example), should be considered a human right. He ends this part of his statement with the words: "wasting water will not cease as long as water has no value." It becomes very clear, that Brabeck sees himself as a defender of the human rights himself, whereas a lot of NGOs and human rights activists see him as the opposite. Later in the same statement, Brabeck points out that bottled water stands in no competition with safe tap water, but with other drinks, e.g., soft drinks. ${ }^{32}$ However, most human rights organisations and NGOs do not agree with Nestles argumentation and promote different models of resistance. A lot of organisations (e.g.: SumOfUs) are building an opposition to Nestle. They are trying to raise awareness to certain water insufficiency problems in rural areas by publishing content on the internet and attaching petitions that people all over the world can sign online. ${ }^{33} \mathrm{~A}$ lot of organisations and activists suggest their readers to boycott the Nestle corporation by stopping to buy any products of brands that belong to the Nestle Group. Some bloggers even appeal for consumers in the western world to completely give up buying bottled drinking water at all, as long as there is safe tap water accessible. ${ }^{34}$ Other sources try to promote more politically and economically related solution models as Public-Public Partnerships, which mean that instead of privatising water systems, municipalities can partner together through public-public partnerships and therefore improve public services and reduce costs, while allowing communities to retain local control. Another solution men-

${ }^{31}$ Example can be found here: https://actions.sumofus.org/a/nestle-water-pakistan (access: 14. 03.2017).

32 http://www.nestle-waters.com/Documents/Bottled_Life_EN_August_2013.pdf (access: 24. 05.2017).

${ }^{33}$ https://actions.sumofus.org/a/nestle-water-pakistan (access: 14.03.2017).

${ }^{34} \mathrm{http}: / /$ foodieunderground.com/nestle-privatization-water-boycott-bottled-water/ (access: 30 . 05.2017). 
tioned is building a so-called Clean Water Trust Fund, which is a source of public funding that will help public utilities protect valuable water resources. ${ }^{35}$ Additionally, one can mention the impact of the company's general reputation on its actions. For marketing purposes Multinational corporations like Nestle are in need to maintain a responsible and positive reputation throughout the world. As mentioned above, the movie Bottled Life from 2012 showed a rather negative picture of the corporation. In Nestle's response to the movie on their homepage can be found a statement concerning the village of Bhati Dilwan, which says that in July, 2014 the most recent clean drinking water facility was installed in the village. The fact, that two years after Nestle was criticised by the movie Bottled Life, and got a lot of negative multimedia attention, therefore suffered a break in the intended image of being a commendable company providing health and nutrition around the world, the corporation built a clean drinking facility in the particular area that was critisised in the movie, might lead to the question if maybe multimedia sources, such as documentary movies can raise awareness and help to improve the rural people's life by putting multinational corporations and companies under pressure to improve the conditions in the areas that they harmed in the first place. ${ }^{36}$

\section{Foucault's concept of power applied on the discourse of Nestle's privatisation of drinking water in Pakistan (analysis)}

To analyse the different lines of argumentation of the in the discourse partaking actors which are mentioned above, it is necessary to give a short introduction on the Foucauldian perception of power. Michael Foucault, who is also a godfather of CDA, primarily focuses on the structure of power and on what is accepted knowledge about how to exercise power. He sees power as a systemic and constitutive element of society (Foucault 1975). Therefore, power should not be limited to repression, exclusion or negation, but should be seen as a productive aspect of power relations that create elements of things and knowledge and produce discourses (Foucault 1976: 114). Elementary for Foucault's perception of power is his concept of "discipline". Following his definition, discipline means a mode of social organization that is internalised in the individual. This internalisation of society given rules is shown in ways of thinking, knowing and behaving. Those rules and practices are learned and practiced through the teaching of correct and incorrect behavior by institutions as for example school, university, military etc. When

${ }^{35} \mathrm{http} / / /$ www.foodandwaterwatch.org/insight/water-privatization-facts-and-figures (access: 16. 03.2017).

${ }^{36} \mathrm{http}: / /$ www.nestle.com/ask-nestle/environment/answers/water-business-bottled-life-documentary (access: 30.05.2017). 
a mode of thought reaches unquestionable acceptance as "normal", it is internalised as a social norm. The maintenance of disciplinary power is managed through systems of surveillance. Those who violate the accepted norms are identifiable and therefore enabling sanctions to be applied, whereas those who are conform are rewarded (Evans 2005: 1005). As Ivan Mankokha puts it, for Foucault "power is positive, it produces behavior that is in conformity with the dominant standard of normality or acceptability" (Manokha 2009: 430).

Now it is important to see how power relations can be distributed following the argumentations within these "social norms" regarding the discourse of resource privatisation.

At the beginning of the essay I already mentioned the relevance of the definition of water as a "human right", but to understand the context of the discourse in a complex way it is necessary to give a short insight into the historical context of the appearance of human rights as a "social norm".

Human rights first appeared internationally with the adoption of the UN Charter in 1945 and the Universal Declaration of Human Rights 1948. Nevertheless, at that point it was denied by the USSR, mostly regarding the rights to private property, which were opposed to socialist system ideologies. In this discourse as well, socialist systems used the argumentation that "the west economically exploits people" with putting emphasis to social rights to justify their nondemocratic systems (Freeman 2002: 47). However, by the end of the Cold War and the transition of socialist countries to capitalism, adoption of democratic human rights was more or less indispensable. The end of the Cold War was interpreted as victory of democracy; therefore, it became the self-assigned task of the west to promote human rights around the world. There is no space here to get into detailed description of the exact actions of the UN. For the understanding of the papers concern it is important that for the human rights to become a "social norm" the UN Security Council authorized some military actions in the $1990 \mathrm{~s}^{37}$ to make sure human rights are being recognised and respected everywhere. This procedure shows what Foucault understands within the term of "disciplination". Nowadays, thanks to the promotion of human rights and sanctioning of nonconform behavior by several actors, governments and NGOs, human rights are perceived as "self-evident" or "common-sense" by a large amount of people and actors (Manokha 2009: 438-439).

Now, to apply this concept onto the example of Nestles drinking water privatisation practices in Pakistan, it is necessary to name the different actors again and uncover the ideology that they stand for. The actors in this discourse are the multinational corporation "Nestle Waters" (which stands for the economic worldview of capitalist society), NGOs (which stand for the ecodevelopmentalistic view), Media (which stand for individuals and mass perceptions/influencer) and the

${ }^{37}$ Last Allies Pull Out of North Iraq, "Financial Times", 16 July 1991, p. 6. 
rural people (which stand for the victims of globalisation). As seen in the argumentations above, "Nestle Waters" promotes its commitment to human rights and this commitment is a big part of the companies brand image and symbolic power structure. As we've learned earlier, human rights are nowadays connoted as a "social norm". As a multinational corporation Nestle commits to human rights through "self-disciplination" towards a social norm and widely accepted structure of what is right. If we now interconnect this commitment with the contributions of Arturo Escobar, the behavior of Nestle is put into an understandable and reasonable context. Nestles position could be described as a "commitment to human rights in a ecodevelopmentalist context and understanding." In a capitalist system of free markets, the line of argumentation of Nestle goes in line with the line of argumentation of ecodevelopmentalists, as their positioning is described by Arturo Escobar. The argumentation lies within the sustainable appreciation of scarce resources (as for example clean drinking water) by giving the resource a value and treating it as a commodity. This shows the influencing power that the human right discourse has on the line of argumentation of the corporation. Additionally, it can be seen that Nestle operates with the capitalistic "common sense" by referring to free markets and growth while simultaneously committing to the democratic concept of human rights. This line of argumentation can seem plausible for people of the western countries, where clean tab water is an obviousness and water is being extendedly used for more than just surviving purposes. But what happens, if we apply this line of argumentation to the rural people of Pakistan who are not able to pay for water as a commodity, and therefore are denied access to clean drinking water due to drying dwells in their villages? Ivan Manokha sees this development in a way that "this is not to say that corporations now indeed do care about human rights, it is only the fact that they find it necessary to claim that they do, and to engage in practices that help promote human rights" (Manokha 2009: 443). Furthermore, Nestle exercises power towards the inhabitants of Pakistan by using an additional practice. In the words of Ruth Wodak: "suggesting how happy people will become if they buy specific consumer products is also an exercise of power" (Wodak 2009: 9). Therefore, Nestle uses its marketing strategies of propagating an image of pure health with its bottled water brand "Pure Life" in Pakistan, to exercise specific power on the inhabitants of Pakistan. This idealisation of the image of bottled water in Pakistan might be seen as reinforcing the exclusion of the poor rural communities, who are not able to pay for the expensive drinking water. So far so good, but what role do NGOs play in this scenario?

NGOs, whose influence grew noticeably after the end of the Cold War, are participants of setting the framework for governments, corporations and international organisations by constituting an opposition to those institutions. In the case of Nestle, there are a lot of NGOs, who contributed to raising awareness on the situation of the population of Bhati Dilwan and their denied access to clean drinking 
water. By officially suggesting Nestles behavior as "ethically incorrect", they have an influence on the western consumers' attitude towards products that are produced by Nestle. Again, this effect of influence is just achievable because of the western populations internalisation of human rights as an "established standard", which are now, as represented by the NGOs, not complied with by Nestle. So NGOs have the ability to practice power towards corporations by influencing the consumers behavior, which on the other hand puts Nestle into a position, where they have to reinstate their "clean" image by at least rectifying the conditions, that the NGOs raised awareness about, to make sure not to lose customers in the west. The media have a similar role. With the movie Bottled Life by Urs Schnell the rural population of Bhati Dilwan has been given a voice. This played a big role in proving the credibility of the accusations against Nestle. To cite Ruth Wodak once again: "Power does not necessarily derive from language, but language can be used to challenge power, to subvert it, to alter distributions of power in the short and the long term" (Wodak 2009: 10). When it comes to documentary movies though, we have to keep in mind that the maker choses its sources and might not show all the aspects of a given situation, but just the ones that suit the research purpose. As can be seen in the media environment and in the positions above, this movie started a big discourse on multimedia platforms and websites, because it made the story and fate of the people of Bhati Dilwan tangible for a large amount of people. To give the affected community of Bhati Dilwan a way of telling their story to the world and the effect this had in a multimedia environment shows the power that modern mass media can exercise within different levels and how it can start and influence already existing discourses.

Finally, as we can see, following the analysis above, when it comes to power relations, objects or actors, that exercise power, can be interconnected and substituted. Their lines of argumentation work on different levels and there is no actor that is independent of other partaking discourse actors.

\section{Conclusion}

Conclusively, the situation of the privatisation of natural resources can be viewed is very controversially discussed. Water is a necessity for human survival. In some places of the world it is hardly accessible for the rural populations, which makes healthy survival almost impossible, whereas in other areas of the world clean drinking water is taken for granted and yet being "wasted" for entertainment purposes etc. In this essay we tried to examine the different lines of argumentations of the partaking actors and their interconnectedness, as well as to exemplary contextualise these argumentations with help of the Foucauldian concept of power. The discourse results of the discrepancy between on the one hand our capitalistic and profit-oriented system, which includes billions of dollars of profit and on the other 
hand the poor people that suffer diseases due to the lack of clean drinking water caused by this profit-orientation. Both sides have their own argumentations and points of views. Privatisation of natural resources might have its positive attributes and might seem legitimate when putting the argumentation into a western context, but one has to keep in mind the situation of the non-privileged people in other parts of the world, that suffer. At this point, it is important to find a solution that suits both sides and to prevent any harm from the rural communities. To end this essay with the words of Paul Farmer:

\begin{abstract}
It's merely the argument that market alone will not solve the greatest problems of our time. It's the argument that even though we are not from the public-sector, we need to do everything in our power to make sure that the public sector does not shrivel and die. Why? (...) Not only because we need the participation of governments to address the current environmental crises at transnational scale needed to make a difference. There is another reason to fight the gutting of the public sector: only governments confer rights. The right to health care and education can be moved forward by people like us, but NGOs, universities, foundations, and forward-thinking businesses are not, alas, in the business of conferring rights. And without basic rights to water, security, health care, and the freedom of from starvation, then the world's poor do not have much hope of a bright future (Farmer \& Clinton 2013: 86).
\end{abstract}

We must ask ourselves if our capitalistic system is worth using other people's resources, which are necessary to them and sometimes can decide over life and death. From an anthropological perspective, this field of resource insecurities has not been sufficiently researched yet and holds many interesting aspects for future research.

\title{
Bibliography
}

Bartel D., Ullrich P., Ehrlich K.

2008 Kritische Diskursanalyse: Darstellung anhand der Analyse der Nahostberichterstattung linker Medien In Kritik mit Methode?: Forschungsmethoden und Gesellschaftskritik, ed. U. Frelkamp, M. Leanza, J. Mende, Berlin, p. 53-72.

Butterley J., Sheperd J.

2010 Hunger: the Biology and Politics of Starvation, Hanover, NH.

Checkley W. et al.

2004 Effect of Water and Sanitation on Childhood Health in a Poor Peruvian Peri-urban Community, "Lancet", Vol. 363, p. 112-118.

Devereux S.

1993 Theories of Famine, New York.

Escobar A.

2012 Encountering Development, Princeton.

Evans T.

2005 International Human Rights Law as Power/Knowledge, "Human Rights Quarterly", Vol. 27, p. 1046-1068. 
FAO (Food and Agriculture Organization)

2002 The State of Food Insecurity in the World 2001, Rome.

Farmer P., Clinton B.

2013 To Repair the World. Paul Farmer Speaks to the Next Generation, California.

Ferry E.E., Limbert M.E.

2008 Introduction, [in:] The Politics of Resources and Their Temporalities, ed. T. Assets, Santa Fe, p. 3-24.

"Financial Times"

1991 Last Allies Pull Out of North Iraq, 16 July, p. 6.

Foucault M.

1975 Der Fall Riviere. Materialien zum Verhältnis von Psychatrie und Strafjustiz, Frankfurt am Main.

1976 Überwachen und Strafen. Die Geburt des Gefängnisses, Frankfurt am Main.

Freeman M.

2002 Human Rights: An Interdisciplinary Approach, Cambridge.

General Assembly Resolution

2200 A (XXI) of December 16, 1966; ICescR entered into force on January 03, 1976 U.N. Doc. A/RES/2200 A (XXI).

Global Water Supply and Sanitation Assessment (Report)

2000 World Health Organization and United Nations Children's Fund: Water Supply and Sanitation Collaborative Council, New York-Geneva.

Government of Pakistan (Ministry of Environment / Pakistan Environment Protection Agency)

2003 Clean Drinking Water Initiative Project, Revised PC-I, Vol. 4, Islamabad.

Government of Pakistan (Ministry of Water and Power / Office of the Chief Engineering

Advisor / Chairman Federal Flood Commission)

2002 Pakistan Water Sector Strategy - Detailed Strategy Formulation, Vol. 4, 111, Islamabad.

Hadley C., Crooks D.L.

2012 Coping and the Biosocial Con-sequences of Food Insecurity in the $21^{\text {st }}$ Century, "Yearbook of Physical Anthropology", Vol. 149(S55), p. 72-94.

Hadley C., Wutich A.

2009 Experience-based Measures of Food and Water Security: Biocultural Approaches to Grounded Measures of Insecurity, "Human Organization”, Vol. 68, p. 451-460.

Hasan K.Z. et al.

1989 Lack of Impact of a Water and Sanitation Intervention on the Nutritional Status of Children in Rural Bangladesh, "European Journal of Clinical Nutrition", Vol. 43, p. 837-843.

Lansing J.S.

1987 Balinese "Water Temples" and the Management of Irrigation, "American Anthropologist", Vol. 89, p. 326-341.

Lansing J.S., Kremer J.N.

1993 Emergent Properties of Balinese Water Temple Networks: Coadaptation on a Rugged Fitness Landscape, “American Anthropologist”, Vol. 95, p. 97-114.

Little M.A., Leslie P.W.

1999 Turkana Herders of the Dry Savanna, Oxford. 
Manokha I.

2009 Foucault's Concept of Power and the Global Discourse of Human Rights, "Global Society", Vol. 23 (4), p. 429-445.

Nestle

2003 Sustainability, Protection, Stewardship, p. 10, http://www.nestle.com (access: 16.03.2017).

Orlove B., Caton S.

2010 Water Sustainability: Anthropological Approaches and Prospects, "Annual Review of Anthropology", Vol. 39, p. 401-415.

Ostrom E.

1990 Governing the Commons: the Evolution of Institutions for Collective Action, Cambridge.

Punjab Amendment Act

1952 Extension Act 1964. West Pakistan Amendment 1965, 1968. Ordinance 1970, and Punjab Amendment Ordinance 1970, 1971 and 1975; The Punjab Soil Reclamation Act, 1952 was Amended by West Pakistan Amendment Ordinance 1964, by which the Soil Reclamation Board was substituted by Land and Water Development Board; For regulation of groundwater in Province of Punjab see: Water and Power Development Authority, Act 1958, Punjab Soil Reclamation Act. 1952 and Rules issued in 1965.

Richardson T., Weszkalnys G.

2014 Resource Materialities. Introduction, “Anthropological Quarterly”, Vol. 87, p. 5-19.

Rogers P. et al.

2002 Water is an Economic Good, "Water Policy", Vol. 4, p. 1-17.

Sachs W.

1988 The Gospel of Global Efficiency, "IFDA Dossier”, No. 68, p. 33-39.

Stevenson G.J. et al.

2012 Water Insecurity in 3 Dimensions: An Anthropological Perspective on Water and Women's Psychosocial Distress in Ethiopia, "Social Science \& Medicine", Vol. 75, p. 392-400.

The United Nations System in Pakistan

2003 Water - A Vital Source of Life, Islamabad, p. 58-63.

United Nations Sub-Commission on the Promotion and Protection of Human Rights

Norms of the responsibility of transnational corporations and other business enterprises with regard to human rights, U.N. Doc. E/CN.4/Sub.2/2003/12/Rev.2, Article 1; adopted with Commentary, U.N.Doc.E/CN.4/Sub.2/2003/38/Rev.2, by Resolution 2003/16 on August 13, 2003, U.N. Doc. E/CN.4/Sub.2/RES/2003/16.

Universal Declaration of Human Rights

1948 General Assembly Resolution 217A (III) of December 10, 1948; U.N. Doc A/810 at 71 .

Whittington D., Mu X., Roche R.

1990 Calculating the Value of Time Spent Collecting Water: Some Estimates for Ukunda, Kenya, "World Development", Vol. 18, p. 269-280.

Wodak R.

2009 Critical Discourse Analysis: History, Agenda, Theory and Methodology, [in:]

Methods for Critical Discourse Analysis, eds. R. Wodak, M. Meyer, London, p. 1-31.

World Health Organization and United Nations Children's Fund: Water Supply and Sanitation Collaborative Council, [in:] Global Water Supply and Sanitation Assessment (Report), New York / Geneva 
Wutich A., Brewis A.

2014 Food, Water, and Scarcity: Toward a Broader Anthropology of Resource Insecurity, "Current Anthropology" 55, No. 4, p. 444-468.

Wutich A., Ragsdale K.

2008 Water Insecurity and Emotional Distress: Coping with Supply, Access, and Seasonal Variability of Water in a Bolivian Squatter Settlement, "Social Science \& Medicine", Vol. 67, p. 2116-2125.

\section{Electronic sources}

http://aaj.tv/2012/04/contaminated-water-contributes-to-40-death-in-pakistan-un/ (access: 16.03.2017).

http://academic.evergreen.edu/g/grossmaz/VANOVEDR/ (access: 16.03.2017).

https://actions.sumofus.org/a/nestle-water-pakistan (access: 14.03.2017).

http://america.aljazeera.com/opinions/2014/4/watermanagementprivatizationworldbankgroupifc.html (access: 15.03.2017).

http://blogs.ei.columbia.edu/2010/09/02/what-is-the-benefit-of-privatizing-water/ (access: 16.03.2017).

http://bottledlifefilm.com/index.php/downloads-for-media.html (access: 26.05.2017). https://canadians.org/fr/node/8154 (access: 24.05.2017).

http://www.foodandwaterwatch.org/insight/water-privatization-facts-and-figures (access: 16.03.2017).

http://foodieunderground.com/nestle-privatization-water-boycott-bottled-water/

(access: 30.05.2017).

http://www.nestle.com (access: 16.03.2017).

http://www.nestle.com/aboutus/overview (access: 16.03.2017).

http://www.nestle.com/ask-nestle/environment/answers/water-business-bottled-life-documentary (access: 30.05.2017).

http://www.nestle-waters.com/aboutus (access: 16.03.2017).

http://www.nestle-waters.com/aboutus/key-figures (access: 16.03.2017).

http://www.nestle-waters.com/bottled-water (access: 16.03.2017).

http://www.nestle-waters.com/brands/all-brands/all-brands-list?char=B (access: 16.03.2017). http://www.nestle-waters.com/Documents/Bottled_Life_EN_August_2013.pdf(access: 24.05.2017).

http://www.unesco.org/bpi/wwdr/WWDR_chart2_eng.pdf (access: 13.03.2017).

http://urbantimes.co/2013/06/nestle-the-global-search-for-liquid-gold/ (access: 16.03.2017). http://www.who.int/ (access: 15.03.2017).

http://www.world-psi.org/en/organisations-denounce-nestles-new-human-rights-impact-assessment (access: 24.05.2017).

https://www.youtube.com/watch?v=qyAzxmN2s0w (access: 16.03.2017).

http://www.3sat.de/page/?source=/boerse/magazin/169630/index.html (access: 16.03.2017). 